\title{
PEMANFAATAN SAMPAH PLASTIK UNTUK DIJADIKAN BANTAL YANG BERKUALITAS DAN BERNILAI EKONOMIS DI DESA TOLADA KECEMATAN MALANGKE KABUPATEN LUWU UTARA
}

\author{
Didiharyono $^{1}$, Andi Mattingaragau Tenrigau ${ }^{2}$ dan Marsal $^{3}$ \\ ${ }^{1}$ Email: muh.didih@gmail.com \\ Dosen Universitas Andi Djemma \\ ${ }^{2}$ Email: andimattingaragau@gmail.com \\ Dosen Fakultas Ekonomi Universitas Andi Djemma \\ ${ }^{3}$ Email:mkalabe@gmail.com \\ Dosen Fakultas Ekonomi Universitas Andi Djemma
}

\begin{abstract}
Abstrak. Penumpukan sampah merupakan masalah lingkungan hidup yang harus ditangani serius karena dapat mengakibatkan kerusakan dan pencemaran lingkungan. Salah satu cara digunakan untuk menanggulangi jumlah sampah plastik adalah dengan memanfaatkannya untuk dijadikan barang-barang hiasan dan juga dimanfaatkan sebagai alternatif pengisi bantal. Oleh karena itu, perlu dilakukan kegiatan pelatihan mengolah dan memanfaatkan sampah plastik menjadi bantal yang berkualitas dan bernilai ekonomis. Kegiatan ini berkerjasama dengan pemerintah Desa Tolada Kecamatan Malangke dan melibatkan ibu-ibu rumah tangga dalam kegiatan tersebut. Kegiatannya dibagi dalam 3 (tiga) tahapan yaitu (a) penjelasan materi umum tentang pemanfatan sampah; (b) tahapan persiapan dan pengumpulan; (c) tahapan pembuatan bantal dari sampah plastik. Pemanfatan sampah plastik menjadi bantal yang berkualitas sangat diperlukan bagi masyarakat. Salah satu tujuannya adalah mengurangi penumpukan sampah plastik dapat menimbulkan berbagai dampak negatif. Pemanfaatan sampah plastik dalam rangka menciptakan lingkungan yang bersih dan sehat. Untuk pengolahan sampah plastik ini ini melibatkan ibu-ibu rumah tangga. Hasil bantal yang dibuatnya bisa bisa digunakan keperluan dalam rumah tangga atau bisa dijual untuk kebutuhan konsumen. Setelah dilakukan perhitungan biaya (cost) yang dikeluarkan, maka bisa diestimasi harga jual yang bisa dipasarkan pada masyarakat antara Rp.20.000 sampai Rp.30.000 tergantung bentuk dan motif (style) yang ada pada bantal tersebut.
\end{abstract}

Kata Kunci: Sampah Plastik, Bantal Berkualitas dan Bernilai Ekonomis

\section{PENDAHULUAN}

Lingkungan yang bersih dan indah adalah harapan semua orang. Di mana pun tempatnya, kondisi yang bersih akan berdampak pada kehidupan yang sehat. Hidup yang sehat akan tercipta bila lingkungannya bersih dan tertata dengan rapi. Selama ada sampah di sekitar kita, maka yakin dan percaya kondisi lingkungan tersebut belum menjadi lingkungan yang sehat.

Keberadaan sampah sangat mempengaruhi kehidupan manusia dalam kesehariannya. Dari berbagai kegiatan baik dari rumah tangga, tempat bekerja, pasar, kantor dan lain-lain selalu ada saja sampah yang dihasilkan. Di desa maupun di kota persoalan sampah menjadi persoalan utama yang mempengaruhi kondisi lingkungan. Hal ini disebabkan karena berbagai faktor seperti gaya hidup, perilaku konsumtif dan hidup yang mengandalkan pada makanan siap saji. Menurut Yenie dkk (2016) masyarakat yang tidak mengindahkan masalah sampah yang sebenarnya mereka adalah sumber terbesar sebagai penghasil sampah. 
Berdasarkan Undang-Undang Republik Indonesia Nomor 18 Tahun 2008, sampah adalah sisa kegiatan sehari-hari manusia dan/atau proses alam yang berbentuk padat. Sampah diklasifikasikan menjadi 3 (tiga) jenis yaitu: (a). Sampah rumah tangga, (b). Sampah sejenis sampah rumah tangga, dan (c). Sampah spesifik. Sampah yang dihasilkan oleh aktivitas manusia dapat digolongkan berdasarkan beberapa kriteria yang meliputi asal, komposisi, bentuk, lokasi, proses terjadinya, sifat dan jenis.

Sampah merupakan masalah lingkungan hidup yang harus ditangani serius karena dapat mengakibatkan kerusakan dan pencemaran lingkungan serta secara tidak langsung dapat memperparah efek pemanasan global. Misalnya saja sampah plastik setiap tahun telah membunuh hingga 1 (satu) juta burung laut, 100.000 mamalia laut dan ikan-ikan yang tidak terhitung jumlahnya (Rini Anik, 2012).

Dari data Kementrian Lingkungan Hidup (KLH) Tahun 2007 dalam Sofiana (2010) menunjukkan, volume timbunan sampah di 194 kabupaten dan kota di Indonesia mencapai 666 juta liter atau setara 42 juta kilogram, dimana komposisi sampah plastik mencapai 14 persen atau enam juta ton. Tahun 2015, menurut KLH jumlah sampah meningkat hingga mencapai 64 juta ton, $11 \%$ di antaranya merupakan sampah plastik. Termasuk di Sulawesi Selatan khususnya di Kabupaten Luwu Utara jumlah sampah terus meningkat setiap tahun. Hal ini dipengaruhi oleh bertambahnya jumlah penduduk dan meningkatnya jumlah konsumsi makanan siap saji serta makanan instan. Dari data ini bisa dilihat bahwa, apabila sampah ini tidak dapat dikurangi maka akan berdampak negatif bagi lingkungan dan juga alam. Oleh karena itu, sampah plastik tersebut harus dimanfaatkan untuk kebutuhan lainnya.

Pemanfaatan sampah plastik merupakan upaya menekan pembuangan plastik seminimal mungkin dan digunakan untuk pembuatan barang-barang hasil kreatifitas masyarakat. Pemanfaatan sampah plastik dapat dilakukan dengan pemakaian kembali (reuse) maupun daur ulang (recycle) setiap sampah tersebut. Pada umumnya pemanfaatan sampah plastik digunakan dalam skala rumah tangga yaitu dengan pemakaian kembali pada keperluan yang berbeda, misalnya tempat cat yang terbuat dari plastik digunakan untuk ember atau pot bunga. Sedangkan, pemanfaatan sampah plastik dengan cara daur ulang umumnya dilakukan oleh industri pengelohan produk dengan bahan baku plastik.

Beberapa cara digunakan untuk menanggulangi jumlah sampah plastik, diantaranya yaitu dengan membakar atau menimbunnyanya. Namun, proses pembakaran yang kurang sempurna akan menjadi dioksin di udara yang dapat menimbulkan berbagai penyakit yang mempengaruhi proses fotosintesis makhluk hidup. Sehingga, dibutuhkan solusi alternatif untuk menanggulangi permasalahan tersebut yaitu dengan memanfaatkannya untuk dijadikan barangbarang hiasan dan juga dimanfaatkan sebagai alternatif pengisi bantal yang berkualitas dan bernilai ekonomis.

Bantal yang berkualitas adalah bantal yang berdaya tahan lama dengan waktu yang bertahun-tahun. Tidak hanya itu, ia punya keindahan yang memiliki nilai estetika. Menurut Irwan dan Haryono (2015) produk yang berkualitas adalah produk yang keseluruhan ciri dan karateristiknya memberikan kepuasan bagi konsumen serta dapat memenuhi kebutuhannya. 
Salah satu cara untuk meningkatkan kepuasan bagi konsumen yaitu dengan cara membuat produk yang unik dan memiliki keindahan atau bernilai estetika (Hadis \& Nurhayati, 2010). Bila produk tersebut diproduksi sebanyak-banyaknya dan dipasarkan maka akan berdampak pada peningkatan nilai ekonomis masyarakat (Didiharyono, 2011).

Masyarakat Desa Tolada Kecamatan Malangke Kabupaten Luwu Utara, mengambil inisiatif untuk memanfaatkan sampah plastik tersebut. Dan mengambali bagian dalam merawat lingkungan yang bebas dari pencemaran sampah khususnya sampah plastik. Oleh karena itu, bersama mahasiswa Kuliah Kerja Nyata $(\mathrm{KKN})$ mengadakan pelatihan pemanfaatan sampah plastik untuk dijadikan bantal. Dengan harapan bantal yang dihasilkan adalah bantal yang berkualitas dan akan diproduksi sebanyak-banyaknya dalam meningkatkan ekonomi masyarakat.

\section{METODE}

Rancangan kegiatan yang dilakukan yaitu kegiatan pelatihan mengolah dan memanfaatkan sampah plastik menjadi bantal. Kegiatan ini dilaksanakan pada hari Selasa 5 Desember 2017 di Aula Kantor Desa Tolada. Kegiatan ini berkerjasama dengan pemerintah Desa Tolada Kecamatan Malangke dan melibatkan ibu-ibu rumah tangga dalam kegiatan tersebut. Alat dipersiapkan seperti gunting, lilin, ember, korek, benang dan jarum jahit serta sabun. Sedangkan bahan yang dibutuhkan yaitu sampah plastic, kantong plastik transparan (bekas bungkus gula atau yang baru), sarung bantal yang terbuat dari kain dan pengharum lainnya. Adapun kegiatannya dibagi dalam 3 (tiga) tahapan yaitu (a) penjelasan materi umum tentang pemanfatan sampah; (b) tahapan persiapan dan pengumpulan; (c) tahapan pembuatan bantal dari sampah plastik. Hasil pembuatan tersebut bisa digunakan sendiri dalam rumahnya dan bisa juga dijual di pasar jika pembuatannya lebih banyak.

\section{PEMBAHASAN}

Kegiatan pelatihan pengelolaan sampah plastik menjadi bantal di Desa Tolada Kecamatan Malangeke Kabupaten Luwu Utara. Adapun kegiatannya dibagi dalam 6 (enam) tahapan yaitu sebagai berikut:

1. Tahapan penjelasan umum materi tentang pemanfatan sampah

Kegiatan ini dikemas dalam bentuk presentasi dan penjelasan dimana penyaji akan memberikan materi dalam bentuk ceramah dan tanya jawab dengan durasi waktu yang tidak lama. Dalam kegiatan ini semua materi yang berhubungan dengan tema pelatihan yang dipersiapkan dalam bentuk slide persentasi dengan tujuan memudahkan ibu-ibu menyaksikan langsung materi yang disampaikan. Pada kegiatan ini diberikan materi tentang pemanfatan sampah, perbedaan sampah organik dan anorganik, dampak negatif dan positif, serta potensi sampah jika diolah. Tidak hanya itu, masyarakat juga diinformasikan tentang bahaya penimbunan dan pembakaran sampah plastik serta dampak-dampaknya bagi lingkungan.

Dengan harapan agar masyarakat memiliki rasa kepedulian terhadap lingkungan dan kesehatannya. Oleh karena itu, sangat penting proses daur ulang sampah plastik menjadi bantal yang berkualitas dan bernilai ekonomis. Untuk memperkenalkan bentuk bantal yang diolah 
TO MAEGA Volume 1 Nomor 1 , Agustus 2018, hlm : $8-13$

dari sampah plastik dibutuhkan sosialisasi kepada masyarakat. Dan juga menginformasikan atau menjelaskan tentang bahaya penimbunan dan pembakaran sampah plastik serta dampakdampaknya bagi lingkungan dan kesehatan. Agar masyarakat memiliki rasa kepedulian terhadap lingkungan dan perduli dalam menciptkan kondisi masyarakat yang bersih.

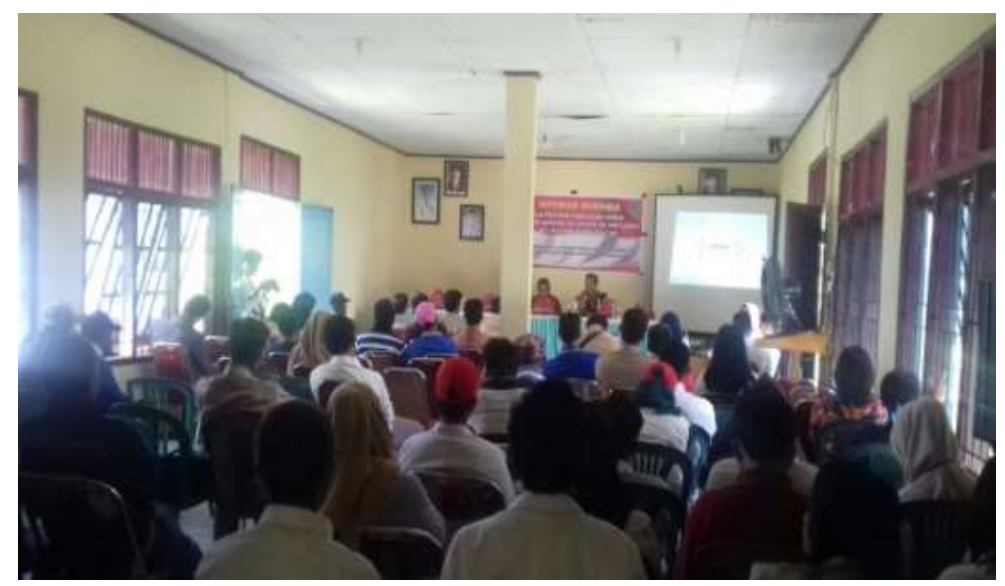

Gambar 1. Kegiatan Menyampaikan Materi

2. Tahapan persiapan dan pengumpulan

Pada tahapan kedua ini, terdapat beberapa langkah yang harus dilakukan yaitu sebagai berikut:

- Mengumpulkan dan memilih sampah plastik sebanyak-banyaknya terutama sampah plastik yang tipis, seperti bekas bungkus makanan ringan, bekas bungkus permen, bungkus mie dan lain-lain.

- Membersihkan sampah plastik yang telah terkumpul tersebut dengan cara mencucinya dengan menggunakan sabun sampai bersih.

- Mengeringkan sampah plastik yang telah dicuci tersebut sampai benar-benar kering dan tidak ada lagi yang kotor.
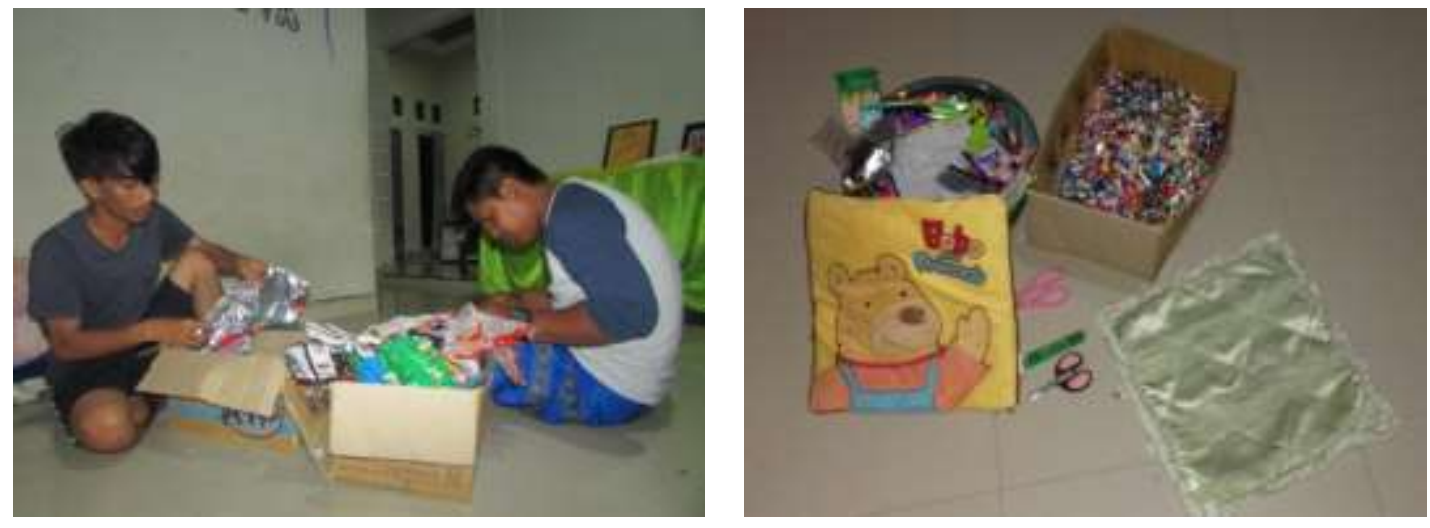

Gambar 2. Kegiatan Persiapan dan Pengumpulan

3. Tahapan pembuatan bantal dari sampah plastik 
Pada tahapan ketiga ini, terdapat beberapa langkah kegiatan yang harus dilakukan yaitu sebagai berikut:

- $\quad$ Setelah sampah kering, sampah plastik tersebut dipotong menjadi sampah yang kecil-kecil dengan ukuran lebih kurang $1 \mathrm{~cm}$ sampai $3 \mathrm{~cm}$.

- Memasukkan potongan-potongan sampah plastik tersebut kedalam kantong plastik yang telah disiapkan.

- $\quad$ Memasukkan pewangi ke dalam kantong plastik tersebut secukupnya agar bantal menjadi harum.

- Melipat ujung kantong plastik dan bakar perlahan-perlahan dengan api lilin untuk mengelem agar kantong plastik tertutup dengan rapat.

- Menjahit resleting di salah satu sisi sarung bantal dan pemasangan hiasan yang indah pada sarung bantal dengan bantuan benang dan jarum jahit secara manual.

- Kantong plastik yang telah terisi dengan potongan-potongan sampah plastik tersebut dimasukkan ke dalam sarung bantal yang telah disiapkan dan menjahit kembali sarung bantal setelah diisi kain.

- Bantal unik sudah jadi dan siap digunakan. Hasil pembuatan tersebut bisa digunakan sendiri dalam rumahnya dan bisa juga dijual di pasar jika pembuatannya lebih banyak.
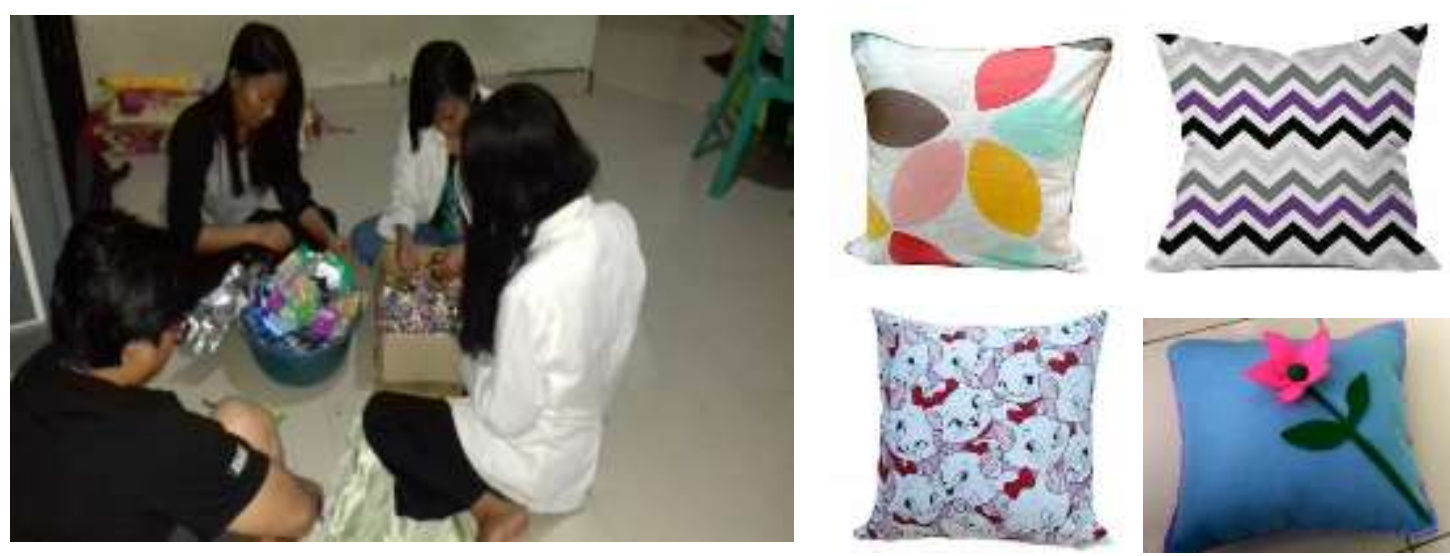

Gambar 3. Proses Pembuatan dan Contoh Produk

Sarung bantal berbahan sampah plastik memiliki beberapa kelebihan daripada bantal dari bahan lainnya. Kelebihannya adalah bisa digunakan dalam waktu yang lebih lama, mudah dicuci, cepat kering dan bisa bertahan dari jamur. Bila dilihat dari segi ekonomis harga sampah lebih murah dan lebih mudah didapatkan dalam kehidupan sehari-hari. Pembuatan batal dari sampah plastik pada prinsipnya bertujuan untuk menanggulangi permasalahan banyaknya limbah plastik yang berada di Desa Tolada. Setelah dilakukan perhitungan biaya (cost) yang dikeluarkan dalam pembuatan dan biaya yang berkaitan dengannya, maka bisa diestimasi harga jual yang bisa dipasarkan pada masyarakat antara Rp.20.000 sampai Rp.30.000 tergantung bentuk dan motif (style) yang ada pada bantal tersebut. Bila produksinya ditingkatkan maka bisa menjadi sumber penghasilan masyarakat baik secara individu atau kelompok.

\section{SIMPULAN}


Pemanfatan sampah plastik menjadi bantal yang berkualitas sangat diperlukan bagi masyarakat. Salah satu tujuannya adalah mengurangi penumpukan sampah plastik dapat menimbulkan berbagai dampak negatif. Pemanfaatan sampah plastik dalam rangka menciptakan lingkungan yang bersih dan sehat. Untuk pengolahan sampah plastik ini ini melibatkan ibu-ibu rumah tangga. Hasil bantal yang dibuatnya bisa bisa digunakan keperluan dalam rumah tangga atau bisa dijual untuk kebutuhan konsumen. Setelah dilakukan perhitungan biaya (cost) yang dikeluarkan, maka bisa diestimasi harga jual yang bisa dipasarkan pada masyarakat antara Rp.20.000 sampai Rp.30.000 tergantung bentuk dan motif (style) yang ada pada bantal tersebut.

\section{DAFTAR PUSTAKA}

Anik, Rini dkk. Sampah Plastik Sebagai Alternatif Pengisi Bantal. Jurnal Ilmiah Mahasiswa, Vol.2 No.1, April 2012.

Didiharyono, D. (2011). Analisis Pengendalian Kualitas Statistik dengan Menggunakan Peta Kendali T-Square (T2)(Studi Kasus Kualitas Produksi Tiang Beton PT Wijaya Karya Beton Makassar) (Doctoral dissertation, Universitas Islam Negeri Alauddin Makassar).

Hadis, A., \& Nurhayati, B. (2010). Manajemen Mutu Pendidikan. Bandung: Alfabeta.

Irwan, I., \& Haryono, D. (2015). Pengendalian Kualitas Statistik (Pendekatan Teoritis dan Aplikatif). Bandung: Alfabeta

Nursruwening, Yohana dkk. Pembuatan Handicraft Menggunakan Bahan Olahan Sampah Domestik. Prosiding Senatek 2015 Fakultas Teknik, Universitas Muhammadiyah Purwokerto, 28 November 2015

Riswan dkk, Pengelolaan Sampah Rumah Tangga Di Kecamatan Daha Selatan. Jurnal Ilmu Lingkungan. Vol.9, No. 1, April 2011

Sofiana, Yunida. Pemanfaatan Limbah Plastik Sebagai Alternatif Bahan Pelapis (Upholstery) Pada Produk Interior. Jurnal Humaniora, Vol.1 No.2 Oktober 2010.

Suyoto, Bagong. 2008, Rumah Tangga Peduli Lingkungan, Jakarta: Prima Media

Tenrigau, A.M., dkk. 2018. Manajemen Sebuah Pengantar. Palopo: Andi Djemma Press

Yenie, Elvi dkk. Peran Serta Masyarakat Dalam Upaya Menciptakan Gerakan Perubahan Budaya Terhadap Pengelolaan Sampah Berbasis Masyarakat Di Kecamatan Lubuk Dalam, Kabupaten Siak. Seminar Nasional Sains dan Teknologi Lingkungan II. Padang, 19 Oktober 2016 